\title{
Production efficiency and agronomic attributes of corn in an integrated crop-livestock-forestry system
}

\author{
Elwira Daphinn Silva Moreira(1), Miguel Marques Gontijo Neto(2), Ângela Maria Quintão Lana(1), \\ Emerson Borghi ${ }^{(2)}$, Claudinei Alves dos Santos ${ }^{(1)}$, Ramon Costa Alvarenga ${ }^{(2)}$ and Maria Celuta Machado Viana ${ }^{(3)}$ \\ (1)Universidade Federal de Minas Gerais, Departamento de Zootecnia, Campus Pampulha, Avenida Antônio Carlos, no 6.627, São Luiz, \\ CEP 31270-901 Belo Horizonte, MG, Brazil. E-mail: daphinn@yahoo.com.br, angelaquintao@gmail.com, cdneisantos@yahoo.com.br \\ (2) Embrapa Milho e Sorgo, Rodovia MG 424, Km 45, Caixa Postal 151, CEP 35701-970 Sete Lagoas, MG, Brazil. E-mail: \\ miguel.gontijo@embrapa.br, emerson.borghi@embrapa.br, ramon.alvarenga@embrapa.br ${ }^{(3)}$ Empresa de Pesquisa Agropecuária de Minas \\ Gerais, Rodovia MG 424, Km 64, Caixa Postal 295, CEP 35701-970 Prudente de Morais, MG, Brazil. E-mail: mcv@epamig.br
}

\begin{abstract}
The objective of this work was to evaluate the agronomic attributes and production efficiency of corn silage and grains in an integrated crop-livestock-forestry (ICLF) system, with intercropping of eucalyptus, corn, and Urochloa cultivars during three crop years. The experimental design was completely randomized, in $2 \times 5 \times 3$ split-split plots with four replicates. The plots consisted of corn cropped between eucalyptus rows (ICLF) and in full sun; the subplots, of the forage grasses U. brizantha 'Marandu', U. brizantha 'Xaraés', U. brizantha 'Piatã', U. ruziziensis, and U. decumbens 'Basilisk'; and the split-split plots, of the 2011/2012, 2012/2013, and 2013/2014 crop years. There was no effect of eucalyptus on the silage and grain yields of corn when intercropped with forages in 2011/2012. The production efficiency of silage and grains decreased by 25 and 48\%, respectively, in 2012/2013 (12-month-old eucalyptus). There was also a 56\% reduction in grain yield in 2013/2014 (24-month-old eucalyptus), compared with full sun. In the year the ICLF system is established, the production efficiency of corn silage and grains is not affected by eucalyptus, but decreases with the development of the trees in the subsequent crop years.
\end{abstract}

Index terms: Urochloa, agrosilvipasture system, eucalyptus, intercrop.

\section{Eficiência produtiva e atributos agronômicos de milho em sistema integração lavoura-pecuária-floresta}

\begin{abstract}
Resumo - O objetivo deste trabalho foi avaliar os atributos agronômicos e a eficiência produtiva de forragem e grãos de milho em um sistema de integração lavoura-pecuária-floresta (ILPF), com consorciação de eucalipto, milho e cultivares de Urochloa, durante três safras. O delineamento experimental utilizado foi o inteiramente casualizado, em parcelas $2 \times 5 \times 3$ sub-subdivididas, com quatro repetições. As parcelas consistiram de cultivo de milho entre renques de eucalipto (ILPF) e a pleno sol; as subparcelas, das forrageiras U. brizantha 'Marandu', U. brizantha 'Xaraés', U. brizantha 'Piatã', U. ruziziensis e U. decumbens 'Basilisk'; e as sub-subparcelas, das safras 2011/2012, 2012/2013 e 2013/2014. Não houve efeito do eucalipto nas produtividades de forragem e grãos de milho consorciado com as forrageiras em 2011/2012. A eficiência produtiva de forragem e grãos teve redução de 25 e 48\%, respectivamente, em 2012/2013 (eucalipto com 12 meses). Também houve redução de 56\% na produtividade de grãos em 2013/2014 (eucalipto com 24 meses), em relação ao cultivo a pleno sol. No ano de implantação do sistema ILPF, a eficiência produtiva de forragem e grãos de milho não é afetada pelo eucalipto, mas é reduzida com o desenvolvimento das árvores nas safras subsequentes.
\end{abstract}

Termos para indexação: Urochloa, sistema agrossilvipastoril, eucalipto, consórcio.

\section{Introduction}

The integrated crop-livestock-forestry (ICLF) system has been introduced in several regions of Brazil, as it allows the continuity of food production by intensifying land use, in order to reduce costs and increase income, and also aggregates sustainability to agricultural enterprises. This system relates the optimization of biological interactions to the synergistic effects between trees and agricultural crops and/or animal husbandry, and provides greater production by area in intercrop, rotation, or succession (Balbino et al., 2011; Vilela et al., 2011; Calil et al., 2016).

The good performance of the ICLF system is due to a number of factors, such as the inclusion of species that are more tolerant to shading, the spatial distribution 
of the species in the area, and management practices that lead to more efficient yield. The introduction of trees in integrated systems increases the potential for carbon capture, which contributes to greater nutrient availability for intercropping, with effects on yield and soil conservation, compared with monocultures (Cordeiro et al., 2015). However, for this to occur, it is imperative that the trees do not compete excessively with the agricultural crop (Alvarenga et al., 2010).

Compared with other crops, corn (Zea mays L.) cultivation for silage or grains is well adapted when integrated with pasture, due to the greater size of the corn plants, which allows them to compete with forage and to be harvested, at ear insertion height, without interference from forage plants (Alvarenga et al., 2010). However, corn may present poor performance in areas shaded by tree canopies in the ICLF system (Mendes et al., 2013).

Forage plant growth, agronomic characteristics, and corn yields in integrated systems are affected by the level of solar radiation that reaches the sub-forest, which is associated with the spatial arrangement and the development of the tree component at the time the cropping system is established (Macedo et al., 2006; Paciullo et al., 2011).

Knowledge about the production efficiency of the annual crop component during the growth of the tree component in ICLF systems is fundamental for technicians and producers to determine the duration of the forest phase of these systems.

The objective of this work was to evaluate the agronomic attributes and production efficiency of corn silage and grains in an ICLF system, with intercropping of eucalyptus, corn, and Urochloa cultivars during three crop years.

\section{Materials and Methods}

The experiment was conducted in the experimental area of Embrapa Milho e Sorgo in Sete Lagoas, in the state of Minas Gerais, Brazil (19² $29^{\prime} 11^{\prime \prime} S, 4^{\circ} 10^{\prime} 77^{\prime \prime} \mathrm{W}$, at an altitude of $708 \mathrm{~m}$ ). The climate of the region is of the Aw type, according to Köppen's classification, with dry season from May to October and wet season from November to April.

The soil is classified as a Latossolo Vermelho distrófico típico, i.e., an Acrustox, with clayey texture, according to the Brazilian Soil Classification System
(Santos et al., 2013), with smooth undulating relief, under cerrado vegetation. The soil of the experimental area presented $111 \mathrm{~g} \mathrm{~kg}^{-1}$ sand, $84 \mathrm{~g} \mathrm{~kg}^{-1}$ silt, and $805 \mathrm{~g}$ $\mathrm{kg}^{-1}$ clay, and the following chemical attributes in the 0-20-cm layer: $\mathrm{pH}\left(\mathrm{H}_{2} \mathrm{O}\right) 5.5,6.94 \mathrm{cmol}^{-1} \mathrm{~cm}^{-3} \mathrm{H}+\mathrm{Al}$, $18.1 \mathrm{mg}^{-1} \mathrm{dm}^{-3} \mathrm{P}$ Mehlich 1, $3.42 \mathrm{dag}^{-1} \mathrm{~kg}$ organic matter, $0.39 \mathrm{cmol}^{-1} \mathrm{dm}^{-3} \mathrm{Al}, 3.16 \mathrm{cmol}^{-1} \mathrm{dm}^{-3} \mathrm{Ca}, 0.35$ $\mathrm{cmol}^{-1} \mathrm{dm}^{-3} \mathrm{Mg}, 68 \mathrm{mg}^{-1} \mathrm{dm}^{-3} \mathrm{~K}$, sum of bases of 3.68 $\mathrm{cmol}^{-1} \mathrm{dm}^{-3}$, cation exchange capacity of 10.62 , base saturation of $35 \%$, and aluminum saturation of $9.57 \%$. In September 2011, $2 \mathrm{Mg} \mathrm{ha}^{-1}$ dolomitic limestone were applied in the experimental area. Data on rainfall and maximum and minimum temperatures during the experimental period are shown in Figure 1.

In October 24, 2011, the GG100 cultivar of eucalyptus (Eucalyptus urophylla S.T.Blake) was planted in six pastures with a length of $100 \mathrm{~m}$ and size of $15 \times 2 \mathrm{~m}$, totaling 333.3 trees per hectare. Clonal seedlings were sown in the furrow and fertilized with $200 \mathrm{~kg} \mathrm{ha}^{-1}$ single superphosphate, plus 120 g N-P $\mathrm{P}_{2} \mathrm{O}_{5}-\mathrm{K}_{2} \mathrm{O}$ (06-3006 ) per plant, with $0.5 \% \mathrm{~B}$ and $1.5 \% \mathrm{Zn}$, half applied on each side of the hole, at a distance of 15 to $20 \mathrm{~cm}$ from the seedling. Cover fertilization was performed under crown projection with 120 g N-P $\mathrm{O}_{5}-\mathrm{K}_{2} \mathrm{O}$ (2000-20) per plant one week after planting and with 200 g per plant in November 2012. Then, in February 2013, $15 \mathrm{~g}$ boric acid were applied per plant under the crown projection of each tree. In September 2013, the trees were stripped to $1 / 3$ of their height. In November 2011, 2012, and 2013, the eucalyptus stands presented mean heights of $0.5,4.8$, and $10.3 \mathrm{~m}$, respectively.

A no-tillage seeder-fertilizer was used to sow AG 8088VT PRO corn seeds simultaneously with $4 \mathrm{~kg} \mathrm{ha}^{-1}$ viable pure seeds of forage grass in the same planting line, both between the eucalyptus stands and in the area with full sun. For this, three rows were spaced $0.70 \mathrm{~m}$ apart, keeping a distance of $1 \mathrm{~m}$ between the first line of corn and forage and the eucalyptus tree stand (tree component), up to a final stand of 68,000 plants per hectare. The area planted with corn intercropped with forage and eucalyptus was of 0.867 ha.

The corn seeds were treated with $135 \mathrm{~g} \mathrm{ha}^{-1}$ imidacloprid $+186 \mathrm{~g} \mathrm{ha}^{-1}$ thiodicarb. Fertilization at the time of sowing consisted of $400 \mathrm{~kg} \mathrm{ha}^{-1} \mathrm{~N}-\mathrm{P}_{2} \mathrm{O}_{5^{-}}$ $\mathrm{K}_{2} \mathrm{O}$ (08-28-16), and, when corn reached the V6-V7 phenological stage, the cover crop was fertilized with $250 \mathrm{~kg} \mathrm{ha}^{-1}$ urea (Souza \& Lobato, 2004). The seeds of the grasses were treated with $5 \mathrm{~g} \mathrm{ha}^{-1}$ fipronil. 
The control of invasive plants was carried out between 15 and 21 days after sowing with the application of 1.5 $\mathrm{kg} \mathrm{ha}^{-1}$ atrazine and $10 \mathrm{~g} \mathrm{ha}^{-1}$ nicossulfurom to slow down the development of the forage.

The experimental design was completely randomized, in $2 \times 5 \times 3$ split-split plots, with four replicates. The treatments consisted of the hierarchical factors: corn in two cropping systems (plot), i.e., between eucalyptus stands (ICLF) and in full sun intercropped with the forage grasses $U$. brizantha
'Marandu', U. brizantha 'Xaraés', $U$. brizantha 'Piatã', $U$. ruziziensis, and $U$. decumbens 'Basilisk' in the planting line (subplot); and three crop years (split-split plots), in this case, the 2011/2012, 2012/2013, and 2013/2014 harvests, after the establishment of eucalyptus trees.

Samplings were performed annually when corn reached the point for silage harvest and the grains around $15 \%$ moisture. The useful experimental plot in the ICLF system consisted of $2.0 \times 4.9-\mathrm{m}\left(9.8 \mathrm{~m}^{2}\right)$ areas, perpendicular to the stands, in which 2 linear meters
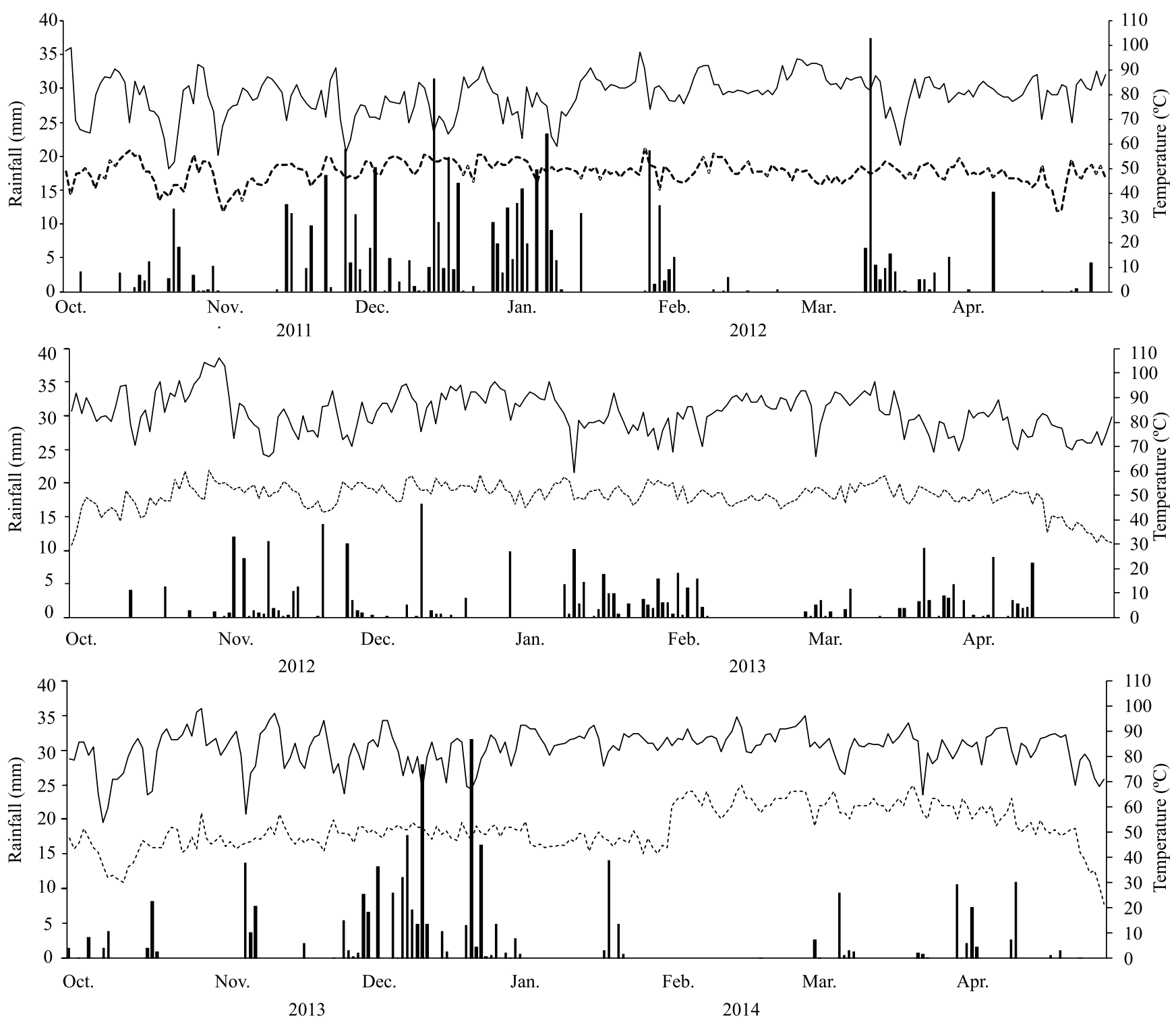

Rainfall Maximum temperature

-.-.-.. Minimum temperature

Figure 1. Mean monthly values of maximum and minimum temperatures and accumulation of rainfall during the experimental period in 2011, 2012, and 2013 (INMET, 2016). 
were evaluated in the first, third, fifth, and seventh corn rows. In the full sun system, the corn intercrop was evaluated in a useful area of $1.4 \mathrm{~m}^{2}(2 \mathrm{~m}$ length $\mathrm{x}$ $0.7 \mathrm{~m}$ width), in the direction of the corn planting line.

In order to evaluate corn silage and forage yields at the ensilage point, the plants in the plots were cut at a height of $20 \mathrm{~cm}$, and corn and forage biomass yields were weighed separately. Flag leaf (FLH) and ear insertion (EIH) heights were measured in two plants per 2-m line. Samples of corn silage and grass forage were dried at $65^{\circ} \mathrm{C}$ in greenhouses with forcedair ventilation for 72 hours to determine dry matter contents and estimate corn silage (CSY) and forage (FY) yields at ensilage time. Total corn silage and forage yield (TSFY) was estimated at ensilage time by adding the corn and forage yields of each plot.

At grain harvest, new plots were defined, where the number of plants and ears was counted, the ear index was obtained, and ears were manually harvested to obtain grain yield. After mechanical threshing, the 1,000-grain weight (TGW) was determined, as well as moisture content corrected to $13 \%$ humidity, in order to calculate the yield and mean weight of grains per ear (MWE), obtained by the relationship between grain weight and the number of ears per plot. With these results, the production efficiency of corn silage (PECS), total corn silage and forage yield (PETSF), and grain yield (PEGY) was calculated. These variables were determined by dividing the estimated silage + forage and grain yields of each treatment in the ICLF system by the average yield of the respective treatment in full sun for each crop year, and the values were converted into percentages.

The data were subjected to the Lilliefors' and Cochran's tests to check normal probability distribution and homoscedasticity, respectively. The analysis of variance was performed, and the means were compared by Tukey's test, at 5 and $1 \%$ probability.

\section{Results and Discussion}

The effect of the interaction cropping system $\mathrm{x}$ forage $\mathrm{x}$ crop year was significant for the structural components FLH and EIH (Table 1). The size of the corn plant and EIH are characteristics associated with genotype, which may also be affected by unfavorable climatic conditions during the plant cycle. It was observed that, in the ICLF system, FLH and EIH were negatively affected by tree growth in 2012/2013 and 2013/2014, compared with 2011/2012 (Table 2). The reduction in plant size was significant for corn intercropped with the $U$. brizantha 'Piatã', $U$. ruziziensis, and $U$. decumbens 'Basilisk' forages.

There was a reduction in plant size in the ICLF system compared with full sun in 2012/2013 and 2013/2014, with a mean reduction of 20 and $47 \mathrm{~cm}$ in FLH, respectively. This was probably due to the increase in the shading level caused by tree growth. Significant differences were observed for FLH in 2012/2013 in the intercrop with the 'Xaraés' and 'Piatã' forages, and in 2013/2014 in the intercrop with U. ruziziensis and U. decumbens 'Basilisk' (Table 2).

Table 1. Mean squares, significance of sources of variation, and their interactions for the evaluated parameters ${ }^{(1)}$.

\begin{tabular}{|c|c|c|c|c|c|c|c|c|c|c|c|}
\hline \multirow{2}{*}{$\begin{array}{l}\text { Sources of } \\
\text { variation }\end{array}$} & \multicolumn{11}{|c|}{ Mean squares } \\
\hline & $\mathrm{PH}$ & $\mathrm{EH}$ & GY & MWE & TGW & EI & PEGY & CSY & TSFY & PECS & PETSF \\
\hline $\mathrm{CS}$ & $1.41 * *$ & $0.53 * *$ & $1.34 \times 10^{8 * *}$ & $26,251.30 * *$ & $21,241.88 * *$ & $80.88^{\text {ns }}$ & $23,710.24 * *$ & $471,760,595.29 * *$ & $473,342,612.74 * *$ & $18,116.77 * *$ & $17,757.51 * *$ \\
\hline Error (a) & 4.42 & 2.42 & 1278991. & 156.11 & 85.46 & 21.83 & 273.21 & 7770421.74 & 9191751.70 & 265.33 & 285.70 \\
\hline $\mathrm{CF}$ & $8.29 * *$ & $3.63 * *$ & $827879.2 *$ & $207.97 * *$ & $232.40^{\mathrm{ns}}$ & $37.14^{\mathrm{ns}}$ & $73.76^{\mathrm{ns}}$ & $16101093.46^{* *}$ & $14227394.36 * *$ & $10.99^{\mathrm{ns}}$ & $15.22^{\mathrm{ns}}$ \\
\hline $\mathrm{CS} \times \mathrm{CF}$ & $4.09^{\text {ns }}$ & $1.22^{\mathrm{ns}}$ & $425370.9^{\mathrm{ns}}$ & $19.94^{\mathrm{ns}}$ & $398.91 *$ & $44.78^{\mathrm{ns}}$ & $73.76^{\mathrm{ns}}$ & $90780.27^{\text {ns }}$ & $78663.58^{\mathrm{ns}}$ & $10.99^{\mathrm{ns}}$ & $15.22^{\mathrm{ns}}$ \\
\hline Error (b) & 1.82 & 1.01 & 243640.5 & 45.07 & 142.8783 & 20.19 & 54.82 & 14063281.14 & 16016395.34 & 524.42 & 548.80 \\
\hline Crop year & $1.18^{* *}$ & $7.70 * *$ & $1.04 \times 10^{8 * *}$ & $24,232.88 * *$ & $189,477.1 * *$ & $20.65 * *$ & $7,143.41 * *$ & $171,305,945.26^{* *}$ & $233,595,880.21 * *$ & $5,700.89 * *$ & $6544.59 * *$ \\
\hline CS x crop year & $0.61 * *$ & $0.16^{* *}$ & $3.32 \times 10^{7 * *}$ & $6,702.17 * *$ & $3,880.98 * *$ & $23.81^{\mathrm{ns}}$ & $7,143.41 * *$ & $138,031,101.99 * *$ & $162,949,928.48 * *$ & $5,700.89 * *$ & $6544.59 * *$ \\
\hline CF x crop year & $7.40^{* *}$ & $4.27 * *$ & $1,805,697.0 * *$ & $275.22 * *$ & $712.28 * *$ & $34.87^{\mathrm{ns}}$ & $30.05^{\text {ns }}$ & $2392210.74^{\mathrm{ns}}$ & $3,541,953.39 * *$ & $41.09^{\mathrm{ns}}$ & $44.64^{\mathrm{ns}}$ \\
\hline $\begin{array}{l}\text { CS x CF x } \\
\text { Crop year }\end{array}$ & $7.93 * *$ & $4.08 * *$ & $105,602.9^{\text {ns }}$ & $55.81^{\mathrm{ns}}$ & $181.04^{\mathrm{ns}}$ & $36.72^{\mathrm{ns}}$ & $30.05^{\mathrm{ns}}$ & $1861762.02^{\mathrm{ns}}$ & $1,960,859.42^{\mathrm{ns}}$ & $41.09^{\mathrm{ns}}$ & $44.64^{\mathrm{ns}}$ \\
\hline Error (c) & 1.37 & 97.92 & $399,047.5$ & 54.65 & 105.79 & 28.84 & 85.51 & $15,578,328.26$ & $15,334,993.18$ & 538.42 & 521.06 \\
\hline CV (\%) & 5.48 & 8.34 & 9.73 & 7.93 & 3.87 & 5.41 & 10.75 & 8.69 & 7.71 & 8.96 & 7.80 \\
\hline
\end{tabular}

${ }^{(1)} \mathrm{CS}$, cropping systems; CF, forage cultivars; $\mathrm{PH}$, corn plant height (m); EH, corn ear height (m); GY, grain yield corrected to $13 \%$ moisture (kg-1 ha); MWE, mean weight of ears (g); TGW, 1,000-grain weight (g); EI, corn ear index; PEGY, production efficiency of corn grain yield (\%); CSY, corn silage yield $\left(\mathrm{kg} \mathrm{ha}^{-1}\right)$; TSFY, total silage and forage yield $\left(\mathrm{kg} \mathrm{ha}^{-1}\right)$; PECS, production efficiency of corn silage (\%); and PETSF, production efficiency of total

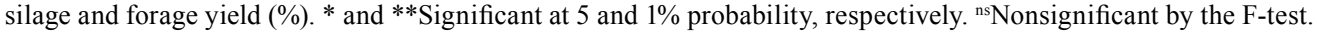


In the intercrop with the forage grasses in full sun, in 2011/2012 and 2012/2013, there were no differences regarding FLH (Table 2). Ramella et al. (2013) also did not find any effect on the development and yield of corn when intercropped with U. brizantha.

In the full sun system, EIH did not differ between crop years, except when corn was intercropped with the Piatã cultivar, which stood out in 2013/2014 (Table 2). In the ICLF, the intercrop with U. ruziziensis and $U$. decumbens presented similar EIH, whereas the others did not differ between crop years. As observed for FLH, tree growth over the crop years also affected EIH, which showed mean reductions of 13 and $26 \mathrm{~cm}$ in 2012/2013 and 2013/2014, respectively.

Silva et al. (2016) evaluated the development of 'BRS 1055' corn in an ICLF system, intercropped with U. ruziziensis between eucalyptus stands; in the Santa
Fé system, also intercropped with U. ruziziensis; and in monocrop. The authors found that the structural components EIH and FLH did not differ according to the systems used.

The effect of the interaction year $\mathrm{x}$ cropping system was significant for CSY, TSFY, GY, TGW, and MWE (Table 1). In the ICLF system, reductions in yields (MWE and TSFY) were observed over the years (Table 3 ), possibly because of the increased competition of the tree component due to its growth and interception of light (shoot) and water and nutrients (roots). In this type of system, the forest component may affect the agricultural and livestock components because of the competition for light, water, and nutrients (Mosquera-Losada et al., 2010). When comparing CSY and TSFY in the ICLF and full sun systems in the 2011/2012 crop year, the average

Table 2. Corn (Zea mays) plant (PH) and ear insertion (EIH) heights in the integrated crop-livestock-forestry (ICLF) and full sun (FS) systems, intercropped with the forages Urochloa brizantha 'Marandú', 'Xaraés', 'Piatã'; U. ruziziensis; and U. decumbens in three crop years ${ }^{(1)}$.

\begin{tabular}{|c|c|c|c|c|c|c|}
\hline \multirow[t]{2}{*}{ System } & \multirow[t]{2}{*}{ Year } & \multicolumn{5}{|c|}{ Intercrop with different forage species } \\
\hline & & Marandú & Xaraés & Piatã & Ruziziensis & Decumbens \\
\hline & & \multicolumn{5}{|c|}{ Plant height (m) } \\
\hline \multirow{3}{*}{ ICLF } & $2011 / 2012$ & $2.26 \mathrm{aA}$ & $2.25 \mathrm{aA}$ & $2.44 \mathrm{aA}$ & $2.37 \mathrm{aA}$ & $2.39 \mathrm{aA}$ \\
\hline & $2012 / 2013$ & $1.84 \mathrm{aA}$ & $1.90 \mathrm{aA}$ & $1.91 \mathrm{bA}$ & $1.87 \mathrm{bA}$ & $1.93 \mathrm{bA}$ \\
\hline & $2013 / 2014$ & $1.88 \mathrm{aA}$ & $1.91 \mathrm{aA}$ & $1.90 \mathrm{bA}$ & $1.82 \mathrm{bA}$ & $1.74 \mathrm{bA}$ \\
\hline \multirow{3}{*}{$\begin{array}{l}\text { Full sun } \\
\text { system }\end{array}$} & $2011 / 2012$ & $2.26 \mathrm{aA}$ & $2.34 \mathrm{abA}$ & $2.22 \mathrm{abA}$ & $2.39 \mathrm{aA}$ & $2.37 \mathrm{aA}$ \\
\hline & $2012 / 2013$ & $2.09 \mathrm{aA}$ & $2.03 \mathrm{bA} *$ & $2.05 \mathrm{bA} *$ & $2.15 \mathrm{aA}$ & $2.16 \mathrm{aA}$ \\
\hline & $2013 / 2014$ & $1.89 \mathrm{aB}$ & $2.59 \mathrm{aA} *$ & $2.57 \mathrm{aA} *$ & $2.19 \mathrm{aAB} *$ & $2.35 \mathrm{aAB}^{*}$ \\
\hline \multicolumn{7}{|c|}{ Ear insertion height $(\mathrm{m})$} \\
\hline \multirow{3}{*}{ ICLF } & $2011 / 2012$ & $1.08 \mathrm{aA}$ & $1.12 \mathrm{aA}$ & $1.27 \mathrm{aA}$ & $1.23 \mathrm{aA}$ & $1.24 \mathrm{aA}$ \\
\hline & $2012 / 2013$ & $1.17 \mathrm{aA}$ & $1.18 \mathrm{aA}$ & $1.16 \mathrm{aA}$ & $1.12 \mathrm{abA}$ & $1.19 \mathrm{abA}$ \\
\hline & $2013 / 2014$ & $1.04 \mathrm{aA}$ & $1.11 \mathrm{aA}$ & $1.03 \mathrm{aA}$ & $0.94 \mathrm{bA}$ & $0.93 \mathrm{bA}$ \\
\hline \multirow{3}{*}{$\begin{array}{l}\text { Full sun } \\
\text { system }\end{array}$} & $2011 / 2012$ & $1.20 \mathrm{aA}$ & $1.26 \mathrm{aA}$ & $1.10 \mathrm{bA}$ & $1.17 \mathrm{aA}$ & $1.21 \mathrm{aA}$ \\
\hline & $2012 / 2013$ & $1.27 \mathrm{aA}$ & $1.23 \mathrm{aA}$ & $1.28 \mathrm{abA}$ & $1.32 \mathrm{aA}$ & $1.37 \mathrm{aA}$ \\
\hline & $2013 / 2014$ & $1.02 \mathrm{aB}$ & $1.50 \mathrm{aA} *$ & $1.41 \mathrm{aA} *$ & $1.21 \mathrm{aAB}^{*}$ & $1.21 \mathrm{aAB} *$ \\
\hline
\end{tabular}

${ }^{(1)}$ Means followed by equal letters, uppercase in the lines and lowercase in the columns, do not differ by Tukey's test, at $5 \%$ probability. $*$ Significant between systems by Tukey's test, at $5 \%$ probability.

Table 3. Corn (Zea mays) grain yield (GY), 1,000-grain weight (TGW), mean weight of ears (MWE), silage yield (CSY), and total silage and forage yield (TSFY) in the integrated crop-livestock-forestry (ICLF) and full sun (FS) systems in 2011/2012, 2012/2013, and 2013/2014 crop years $^{(1)}$.

\begin{tabular}{|c|c|c|c|c|c|c|c|c|c|c|c|c|c|c|c|}
\hline \multirow[t]{2}{*}{ System } & \multicolumn{3}{|c|}{ Grain yield $\left(\mathrm{kg} \mathrm{ha}^{-1}\right)$} & \multicolumn{3}{|c|}{ TGW (g) } & \multicolumn{3}{|c|}{ MWE (g) } & \multicolumn{3}{|c|}{$\operatorname{CSY}\left(\mathrm{kg} \mathrm{ha}^{-1}\right)$} & \multicolumn{3}{|c|}{$\operatorname{TSFY}\left(\mathrm{kg} \mathrm{ha}^{-1}\right)$} \\
\hline & 2011/ & $2012 /$ & 2013/ & 2011/ & $2012 /$ & 2013/ & 2011/ & $2012 /$ & 2013/ & 2011/ & $2012 /$ & 2013/ & $2011 /$ & $2012 /$ & $2013 /$ \\
\hline & 2012 & 2013 & 2014 & 2012 & 2013 & 2014 & 2012 & 2013 & 2014 & 2012 & 2013 & 2014 & 2012 & 2013 & 2014 \\
\hline ICLF & $6,297 \mathrm{aB}$ & $7,024 \mathrm{bA}$ & $2,978 \mathrm{bC}$ & $327.2 \mathrm{aA}$ & $255.8 \mathrm{bB}$ & $173.4 \mathrm{bC}$ & $88.7 \mathrm{aB}$ & $102.7 \mathrm{bA}$ & $43.9 \mathrm{bC}$ & $15,413.2 \mathrm{aA}$ & $12,969.4 \mathrm{bA}$ & $8,034.2 \mathrm{bB}$ & $16,536.7 \mathrm{aA}$ & $13,167.1 \mathrm{bA}$ & $8,117.6 \mathrm{bB}$ \\
\hline FS & $6,529 \mathrm{aB}$ & $9,262 \mathrm{aA}$ & $6,851 \mathrm{aB}$ & $331.0 \mathrm{aA}$ & $293.8 \mathrm{aB}$ & $211.4 \mathrm{aC}$ & $90.6 \mathrm{aC}$ & $136.2 \mathrm{aA}$ & $97.2 \mathrm{aB}$ & $15,436.8 \mathrm{aA}$ & $17,439.8 \mathrm{aA}$ & $15,436.7 \mathrm{aA}$ & $16,272.1 \mathrm{aA}$ & $17,581.9 \mathrm{aA}$ & $15,685.6 \mathrm{aA}$ \\
\hline
\end{tabular}

${ }^{(1)}$ Means followed by equal letters, uppercase in the lines and lowercase in the columns, do not differ by Tukey's test, at $5 \%$ probability. 
silage yields were similar, decreasing in the following crops. It should be noted that, in the studied systems, CSY corresponded to $94.0,98.8$, and $98.6 \%$ of TSFY for 2011/2012, 2012/2013, and 2013/2014, respectively, which is an indicative of a low contribution regardless of the system. Gontijo Neto et al. (2014) assessed corn silage and grain yields between lines of 22-monthold eucalyptus and found that the silage yield of corn intercropped with brachiaria decreased around $35 \%$ in comparison with that of the area cultivated without the forest component. The authors also observed that, in the following years, corn yield was even more compromised, with a reduction of $48 \%$ in silage yield and of up to $63 \%$ in grain yield, which can be explained by the greater competition between eucalyptus trees and the crop between stands as the trees grew over the years. Bertomeu (2012) reported a reduction of $19-66 \%$ in shoot biomass and corn GY in an ICLF system composed of cloned eucalyptus hybrids, compared with corn in monoculture, which was also attributed to increased competition for light, water, and nutrients.

Regarding GY, there were no significant differences in this component or in TGW and MWE since eucalyptus was established in 2011/2012, which indicates that the trees did not compete with corn and forages (Table 3). When competition occurs between species, plants undergo morphological changes that directly affect the uptake of radiation and accumulation of photoassimilates, with consequences for corn grain yield (Mendes et al., 2013).

In the following crops (2012/2013 and 2013/2014), there was a significant reduction in GY in the ICLF system compared with full sun, with the highest decreases observed in 2013/2014, which is indicative that the competitive pressure exerted by the tree component on corn and forage crops increases with tree growth (Table 3).

The results of the first harvest (2011/2012) were similar to those verified by Porfírio-da-Silva et al. (2015), who did not find a shading effect on corn yield in the ICLF, in the region of Campos Gerais, in the state of Paraná, Brazil. The authors obtained a mean GY of $4.25 \mathrm{Mg} \mathrm{ha}^{-1}$ in the monocrop and of 4.55 in the ICLF system with eucalyptus with $4.8 \mathrm{~m}$ in height and spaced at $14 \times 3 \mathrm{~m}$.

No significant effect was observed for the interaction cropping system $\mathrm{x}$ intercropped forage cultivars for the variables GY, CSY, and TSFY; however, there was an effect of the interaction crop year $\mathrm{x}$ forage on GY and TSFY (Table 1). These results show that the evaluated forage grasses intercropped with corn did not affect CSY and TSFY in the different cropping systems in the first three years of establishment (Table 4). In relation to GY, corn intercropped with 'Marandú' grass stood out in 2011/2012; however, in 2012/2013, together with the Xaraés cultivar, the GY values were the lowest and there was no significant difference between the different forage cultivars in 2013/2014. Tsumanuma et al. (2012) also found that corn crop yield was not affected by $U$. brizantha and that the production of this grass species is very similar to that of $U$. decumbens when intercropped with corn.

Table 4. Corn (Zea mays) grain yield (GY), total silage and forage yield (TSFY), 1,000-grain weight (TGW), and mean weight of ears (MWE) when intercropped with the forages Urochloa brizantha 'Marandú', 'Xaraés', and 'Piatã'; $U$. ruziziensis; and U. decumbens in three crop years ${ }^{(1)}$.

\begin{tabular}{|c|c|c|c|}
\hline \multirow[t]{2}{*}{ Forage specie } & \multicolumn{3}{|c|}{ Crop years } \\
\hline & $2011 / 2012$ & $2012 / 2013$ & $2013 / 2014$ \\
\hline & \multicolumn{3}{|c|}{ Grain yield $\left(\mathrm{kg} \mathrm{ha}^{-1}\right)$} \\
\hline Marandú & $7,295 \mathrm{aA}$ & 7,541bA & $5,293 \mathrm{aB}$ \\
\hline Xaraés & $6,314 \mathrm{bB}$ & $7,895 \mathrm{bA}$ & $5,032 \mathrm{aC}$ \\
\hline Piatã & $6,230 \mathrm{bB}$ & $8,722 \mathrm{aA}$ & $4,933 \mathrm{aC}$ \\
\hline Ruziziensis & $6,032 \mathrm{bB}$ & $8,034 \mathrm{abA}$ & $4,646 \mathrm{aC}$ \\
\hline \multirow[t]{2}{*}{ Decumbens } & $6,192 \mathrm{bB}$ & $8,523 \mathrm{aA}$ & $4,669 \mathrm{aC}$ \\
\hline & \multicolumn{3}{|c|}{ TSFY $\left(\mathrm{kg} \mathrm{ha}^{-1}\right)$} \\
\hline Marandú & $15,420.94 \mathrm{aA}$ & $15,838.74 \mathrm{aA}$ & $12,205.01 \mathrm{aA}$ \\
\hline Xaraés & $17,202.47 \mathrm{aA}$ & $15,805.28 \mathrm{aA}$ & $13,029.09 \mathrm{aA}$ \\
\hline Piatã & $16,978.31 \mathrm{aA}$ & $16,360.37 \mathrm{aA}$ & $12,442.68 \mathrm{aA}$ \\
\hline Ruziziensis & $16,794.95 \mathrm{aA}$ & $14,148.13 \mathrm{aAB}$ & $10,650.02 \mathrm{aB}$ \\
\hline \multirow[t]{2}{*}{ Decumbens } & $15,632.85 \mathrm{aA}$ & $14,720.02 \mathrm{aA}$ & $10,678.04 \mathrm{aA}$ \\
\hline & \multicolumn{3}{|c|}{ TGW (g) } \\
\hline Marandú & $340.82 \mathrm{abA}$ & $263.91 \mathrm{bB}$ & $199.41 \mathrm{aC}$ \\
\hline Xaraés & 338.08abA & $270.78 \mathrm{abB}$ & $192.96 \mathrm{aC}$ \\
\hline Piatã & $324.01 \mathrm{bA}$ & $281.56 \mathrm{aB}$ & $190.90 \mathrm{aC}$ \\
\hline Ruziziensis & $330.60 \mathrm{bcA}$ & $277.97 \mathrm{aB}$ & $189.81 \mathrm{aC}$ \\
\hline \multirow[t]{2}{*}{ Decumbens } & $311.87 \mathrm{cA}$ & $279.69 \mathrm{aB}$ & $188.85 \mathrm{aC}$ \\
\hline & \multicolumn{3}{|c|}{ MWE (g) } \\
\hline Marandú & $102.10 \mathrm{aB}$ & $112.25 \mathrm{bA}$ & $76.06 \mathrm{aC}$ \\
\hline Xaraés & $91.32 \mathrm{bA}$ & $119.76 \mathrm{abB}$ & $71.48 \mathrm{aC}$ \\
\hline Piatã & $88.15 \mathrm{bA}$ & $124.76 \mathrm{aB}$ & $70.69 \mathrm{aC}$ \\
\hline Ruziziensis & $83.43 \mathrm{bA}$ & $118.38 \mathrm{abB}$ & $66.73 \mathrm{aC}$ \\
\hline Decumbens & $83.34 \mathrm{bA}$ & 121.69abB & $67.65 \mathrm{aC}$ \\
\hline
\end{tabular}

(1) Means followed by equal letters, uppercase in the lines and lowercase in the columns, do not differ by Tukey's test, at $5 \%$ probability. 
This result contrasts with those of Chioderoli et al. (2010), who reported that autumn corn intercropped with $U$. ruziziensis had higher GY values, differing from $U$. brizantha.

The reductions in GY observed between the ICLF and full sun systems probably resulted from decreases in TGW and MWE, which did not differ between systems in the 2011/2012 crop year. These same parameters showed reductions of approximately 13 and $24.6 \%$ and of 18 and 54\%, respectively, in 2012/2013 and 2013/2014.

Regarding the corn ear index, there was a year effect (Table 1), with 1.02 ear per plant in 2011/2012 and 0.99 and 0.97 ear per plant in 2012/2013 and 2013/2014, respectively, probably due to increased shading by trees (Paciullo et al., 2011). Considering that the useful area of the ICLF system sown with corn was 0.867 ha, the yields obtained in 1 ha were 5,459,6,097, and $2,582 \mathrm{~kg} \mathrm{ha}^{-1}$ grains and $14,337,11,416$, and $7,038 \mathrm{~kg}$ $\mathrm{ha}^{-1}$ silage in the 2011/2012, 2012/2013, and 2013/2014 crop years, respectively.

It should be pointed out that the silage + forage and grain yields (GY, CSY, and TSFY) in the full sun system were significantly higher in 2011/2012, probably due to the better climatic conditions, i.e., rainfall distribution, during the corn growing cycle (Table 3 ). When evaluating the production efficiencies of silage + forage (PECS and PETSF) and grain (PEGY) yields in the ICLF system, there was a significant interaction between cropping systems and year (Table 1). In the year the tree component was established (2011/2012), PEGY, PECS, and PETSF showed similar behavior in the first cycle in both cropping systems (Table 5). However, when

Table 5. Production efficiency of corn (Zea mays) grain yield (PEGY), silage (PECSY), and total silage and forage yield (PETSFY) in the integrated crop-livestock-forestry (ICLF) and full sun (FS) systems in three crop years ${ }^{(1)}$.

\begin{tabular}{lcccc}
\hline Variable & System & \multicolumn{3}{c}{ Production efficiency (\%) } \\
\cline { 3 - 5 } & & $2011 / 2012$ & $2012 / 2013$ & $2013 / 2014$ \\
\hline \multirow{2}{*}{ PEGY } & ICLF & $99.85 \mathrm{aA}$ & $75.86 \mathrm{bB}$ & $43.39 \mathrm{bC}$ \\
& FS & $100.0 \mathrm{aA}$ & $100.0 \mathrm{aA}$ & $100.0 \mathrm{aA}$ \\
\hline \multirow{2}{*}{ PECSY } & ICLF & $99.82 \mathrm{aA}$ & $74.36 \mathrm{bB}$ & $52.10 \mathrm{bC}$ \\
& FS & $100.0 \mathrm{aA}$ & $100.0 \mathrm{aA}$ & $100.0 \mathrm{aA}$ \\
\hline \multirow{2}{*}{ PETSFY } & ICLF & $101.64 \mathrm{aA}$ & $74.86 \mathrm{bB}$ & $51.77 \mathrm{bC}$ \\
& FS & $100.0 \mathrm{aA}$ & $100.0 \mathrm{aA}$ & $100.0 \mathrm{aA}$ \\
\hline
\end{tabular}

${ }^{(1)}$ Means followed by equal letters, uppercase in the lines and lowercase in the columns, do not differ by Tukey test, at $5 \%$ probability. compared with the full sun system, ICLF showed a decrease of around $25 \%$ in the production efficiency of silage + forage and grain yield in 2012/2013, and of $48 \%$ in silage yield and $56 \%$ in grain yield in 2013/2014. These reductions in production efficiencies are explained by the interspecific competition for resources, since there is a decrease in the radiation that affects the sub-forest as trees grow (Ding \& $\mathrm{Su}$, 2010; Mosquera-Losada et al., 2010; Bertomeu, 2012; Gontijo Neto et al., 2014).

For silage and grain yield efficiencies, there were no significant effects of forage species used in the intercrop or of their interactions with cropping system and year (Table 5). This is indicative that there was no difference between the forage species evaluated for intercropping with corn and eucalyptus in the first three years of the experiment.

\section{Conclusions}

1. The agronomic attributes, yield, and production efficiency of corn (Zea mays) are not affected by eucalyptus stands in the year of the integrated croplivestock-forestry (ICLF) system is established.

2 . The growth of trees in the harvests following the establishment of the ICLF system increases losses in the production efficiency of corn grains and silage.

3. The cultivars of Urochloa sp. evaluated in the intercrop do not affect the production efficiency of corn grains and silage.

\section{Acknowledgments}

To Embrapa Milho e Sorgo, to rede ILPF, and to Fundação de Amparo à Pesquisa do Estado de Minas Gerais (Fapemig), for financing and carrying out the research; and to Coordenação de Aperfeiçoamento de Pessoal de Nível Superior (Capes), for scholarship granted to the first author.

\section{References}

ALVARENGA, R.C.; PORFÍRIO-DA-SILVA, V.; GONTIJO NETO, M.M.; VIANA, M.C.M.; VILELA, L. Sistema integração lavoura-pecuária-floresta: condicionamento do solo e intensificação da produção de lavouras. Informe Agropecuário, v.31, p.59-67, 2010.

BALBINO, L.C.; CORDEIRO, L.A.M.; PORFÍRIO-DA-SILVA, V.; MORAES, A. de; MARTÍNEZ, G.B.; ALVARENGA, R.C.; KICHEL, A.N.; FONTANELI, R.S.; SANTOS, 
H.P. dos; FRANCHINI, J.C.; GALERANI, P.R. Evolução tecnológica e arranjos produtivos de sistemas de integração lavoura-pecuária-floresta no Brasil. Pesquisa Agropecuária Brasileira, v.46, p.i-xii, 2011. DOI: 10.1590/S0100204X2011001000001.

BERTOMEU, M. Growth and yield of maize and timber trees in smallholder agroforestry systems in Claveria, northern Mindanao, Philippines. Agroforestry Systems, v.84, p.73-87, 2012. DOI: 10.1007/s10457-011-9444-x.

CALIL, F.N.; LIMA, N.L.; SILVA, R.T.; MORAES, M.D.A. de; BARBOSA, P.V.G.; LIMA, P.A.F.; BRANDAO, D.C.; SILVANETO, C. de M.; CARVALHO, H.C. de S.; NASCIMENTO, A. dos R. Biomass and nutrition stock of grassland and accumulated litter in a silvopastoral system with Cerrado species. African Journal of Agricultural Research, v.11, p.3701-3709, 2016. DOI: 10.5897/AJAR2016.11369.

CHIODEROLI, C.A.; MELLO, L.M.M. de; GRIGOLLI, P.J.; SILVA, J.O. da R.; CESARIN, A.L. Consorciação de braquiárias com milho outonal em plantio direto sob pivô central. Engenharia Agrícola, v.30, p.1101-1109, 2010. DOI: 10.1590/ S0100-69162010000600011.

CORDEIRO, L.A.M.; ROBÉLIO, L.V.; MARCHÃO, R.L.; KLUTHCOUSKI, J.; MARTHA JÚNIOR, G.B. Integração lavoura-pecuária e integração lavoura-pecuária-floresta: estratégias para intensificação sustentável do uso do solo. Cadernos de Ciência \& Tecnologia, v.32, p.15-53, 2015.

DING, S.; SU, P. Effects of tree shading on maize crop within a Poplar-maize compound system in Hexi Corridor oasis, northwestern China. Agroforestry Systems, v.80, p.117-129, 2010. DOI: $10.1007 / \mathrm{s} 10457-010-9287-x$.

GONTIJO NETO, M.M.; VIANA, M.C.M.; ALVARENGA, R.C.; SANTOS, E.A. dos; SIMÃO, E. de P.; CAMPANHA, M.M. Sistemas de integração lavoura-pecuária-floresta em Minas Gerais. Boletim Indústria Animal, v.71, p.183-191, 2014. DOI: 10.17523/bia.v71n2p183.

INMET. Instituto Nacional de Meteorologia. Available at: $<$ http://www.inmet. gov.br/portal/>. Accessed on: Feb. 22016.

MACEDO, R.L.G.; BEZERRA, R.G.; VENTURIN, N.; VALE, R.S. do; OLIVEIRA, T.K. de. Desempenho silvicultural de clones de eucalipto e características agronômicas de milho cultivados em sistema silviagrícola. Revista Árvore, v.30, p.701-709, 2006. DOI: 10.1590/S0100-67622006000500003.

MENDES, M.M. de S.; LACERDA, C.F. de; CAVALCANTE, A.C.R.; FERNANDES, F.É.P.; OLIVEIRA, T.S. de. Desenvolvimento do milho sob influência de árvores de paubranco em sistema agrossilvipastoril. Pesquisa Agropecuária
Brasileira, v.48, p.1342-1350, 2013. DOI: 10.1590/S0100$204 X 2013001000005$.

MOSQUERA-LOSADA, M.R.; FERREIRO-DOMÍNGUEZ, N.; RIGUEIRO-RODRÍGUEZ, A. Fertilization in pastoral and Pinus radiata D. Don silvopastoral systems developed in forest and agronomic soils of Northwest Spain. Agriculture, Ecosystems \& Environment, v.139, p.618-628, 2010. DOI: 10.1016/j. agee.2010.10.007.

PACIULLO, D.S.C.; GOMIDE, C.A.M.; CASTRO, C.R.T. de; FERNANDES, P.B.; MÜLlER, M.D.; PIRES, M. de F.Á.; FERNANDES, E.N.; XAVIER, D.F. Características produtivas e nutricionais do pasto em sistema agrossilvipastoril, conforme a distância das árvores. Pesquisa Agropecuária Brasileira, v.46, p.1176-1183, 2011. DOI: 10.1590/S0100-204X2011001000009.

PORFÍRIO-DA-SILVA, V.; MORAES, A. de; MOLETTA, J.L.; PELISSARI, A.; DIECKOW, J.; OLIVEIRA, E.B. de. Produtividade do milho em um sistema silviagrícola nos Campos Gerais, PR. Scientia Agraria, v.16, p.27-32, 2015. DOI: 10.5380/ rsa.v16i1.41044.

RAMELLA, J.R.P.; BATTISTUS, A.G.; SILVA, C. da; LIBARDI, K.D.C.; CASTAGNARA, D.D.; OLIVEIRA, P.S.R. de; NERES, M.A. Influência do sistema lavoura-pecuária com Zea mays L. e Brachiaria brizantha nas variáveis produtivas da cultura do milho. Scientia Agraria Paranaensis, v.12, p.96-104, 2013. DOI: 10.18188/1983-1471/sap.v12n2p96-104.

SANTOS, H.G. dos; JACOMINE, P.K.T.; ANJOS, L.H.C. dos; OLIVEIRA, V.A. de; LUMBRERAS, J.F.; COELHO, M.R.; ALMEIDA, J.A. de; CUNHA, T.J.F.; OLIVEIRA, J.B. de. Sistema brasileiro de classificação de solos. 3.ed. rev. e ampl. Brasília: Embrapa, 2013. 353p.

SILVA, A.R; SALES, A.; CARVALHO, E.J.M.; VELOSO, C.A.C. Dinâmica de sistemas integrados de manejo de um solo no desenvolvimento da cultura do milho. Revista em Agronegócio e Meio Ambiente, v.9, p.859-873, 2016. DOI: 10.17765/2176-9168.2016v9n4p859-873.

SOUZA, D.M.G. de; LOBATO, E. (Ed.). Cerrado: correção do solo e adubação. 2.ed. Brasília: Embrapa Informação Tecnológica; Planaltina: Embrapa Cerrados, 2004. 416p.

TSUMANUMA, G.M.; DETOMINI, E.R.; HALL, T.; FANCELLI, A.L. Establishment of Brachiarias intercropped with maize. Uniciências, v.16, p.45-50, 2012.

VILELA, L.; MARTHA JUNIOR, G.B.; MACEDO, M.C.M.; MARCHÃO, R.L.; GUIMARÃES JÚNIOR, R.; PULROLNIK, K.; MACIEL, G.A. Sistemas de integração lavoura-pecuária na região do Cerrado. Pesquisa Agropecuária Brasileira, v.46, p.1127-1138, 2011. DOI: 10.1590/S0100-204X2011001000003.

Received on February 9, 2017 and accepted on July 12, 2017

Pesq. agropec. bras., Brasília, v.53, n.4, p.419-426, Apr. 2018

DOI: 10.1590/S0100-204X2018000400003 